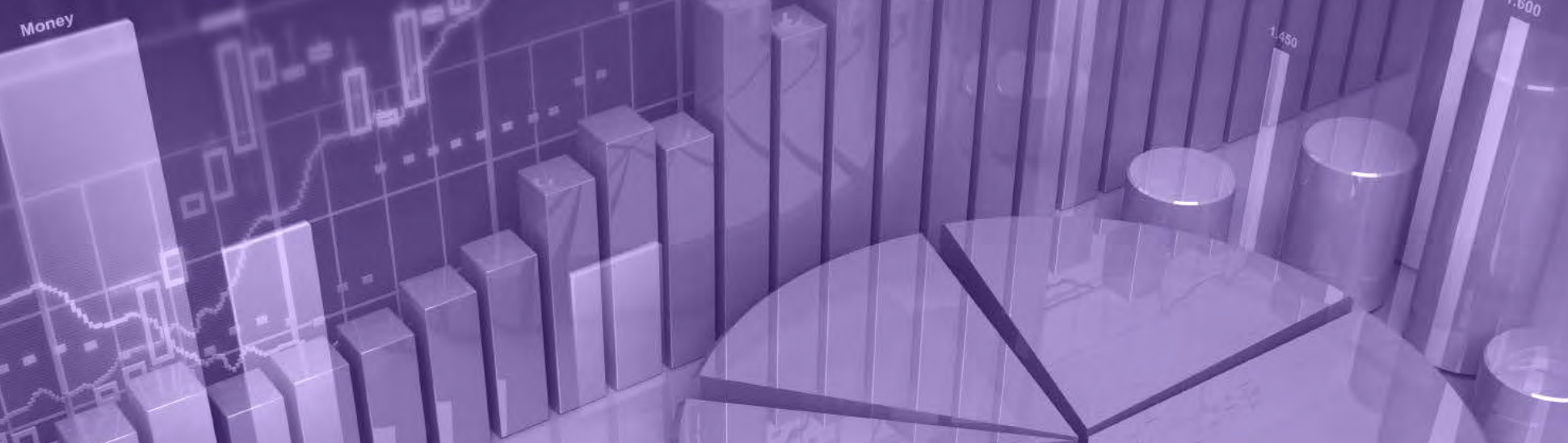

\title{
Latin American iShares: Prices And Premiums
}

\section{By Javier Rodríguez}

Javier Rodríguez, Ph.D. is Professor - Finance, University of Puerto Rico, Graduate School of Business

ETFs have fast become one of the most popular investment instruments not only in developed markets but also in emerging markets. This study examines the prices and premiums of a sample of country-specific Latin American ETFs, a highly popular group of ETFs with investors, but relatively unexplored in academic literature. Regression analysis is used to measure price efficiency and the persistence of deviations from net asset value. I find that although price efficiency is high, other factors, beside fundamental value explain the variation in prices. Most of the ETFs in the sample are more likely to trade at a premium and deviations from net asset value persist at least for a day.

Keywords: Exchange Traded Funds; iShares; Premium

\section{Introduction}

Ever since their introduction in the 1990s exchange traded funds (ETFs) are fast becoming one of the most popular investment vehicles among both individual and institutional investors. ETFs generally represent claims on a diversified portfolio. Most ETFs hold a basket of securities that tracks a specific fixed income index, stock index or other underlying benchmark. In essence, ETFs are openend mutual funds, or unit investment trusts, that can be traded like common stocks. This feature allows investors to buy or sell ETF shares throughout the day. The tradability of ETFs is what differentiates them from open-end index funds. In fact, ETFs are now one of the most traded securities in U.S. exchanges. For example, the Spider (ticker SPY-NYSE) an ETF that tracks the S\&P 500 index, and the Cube (ticker QQQ-NASDAQ) which tracks the Nasdaq-100 index, are both some of the most highly traded securities in their respective exchanges.

Although in comparison to mutual funds, ETF assets represent a small fraction of the total assets managed by investment companies in the U.S., their growth has been significant. According to statistics provided by the Investment Company Institute (ICI), in 2000 there were 80 ETFs and total net assets were $\$ 66$ billion. By the end of 2010 , the total number of ETFs had grown to 923 and total net assets reached $\$ 992$ billion'. One of the reasons every year more investors are lured to ETFs is their diversity, that is ETF investors not only are able to invest in broad market indexes but also able to reap the diversification benefits by, for example, investing in gold ETFs or taking advantage of the outperformance of a foreign market by investing in their respective EFT. In fact, many popular press articles advocate that ETFs have democratized international investing and provide one of the best avenues to access, among others, emerging markets ${ }^{2}$. In all, ETFs provide investor with ample opportunities to own diversified portfolios with the trading benefits of stocks. Given the growth in popularity of ETFs within the investment community, it is only natural to find more and more academic articles devoted to this investment product.

In this paper, I empirically examine the prices and premiums of a sample of ETFs that track a series of Latin American country-specific indexes. There are several reasons why Latin American ETFs present an interesting subject group. For one, they can be used to examine the demand of U.S. or international investors for Latin American securities. More importantly, many of the stocks included 
in the underlying Latin American indexes trade only in their home market, thus ETFs and mutual funds are perhaps the easiest alternatives for U.S.-investors to access some of these securities. Also, while replicating the performance of a Latin American market might be too costly and time consuming for a typical international investor, with ETFs such investors avoid the illiquidity, trading restrictions and changing exchange rates issues common in direct international investing and typical in some of the Latin American countries included in this study. Another reason is the diversification potential provided to international investors by the Latin American region. This is one of the most important facts about Latin American ETFs that the financial press dwells on ${ }^{3}$. Finally, although several ETF studies include Latin American ETFs in their samples and the financial press actively features them, I have no knowledge of a study solely devoted to them ${ }^{4}$.

I focus my attention on a set of Latin American ETFs offered by one of the largest provider of ETFs: iShares. iShares offers ETFs for a vast number of domestic and global market sectors. At present time there are more than 460 different iShares with close to $\$ 500$ billion in assets under management. 5 Given the diversity, breath, and growth of the iShares, they have become one of the most studied groups of ETFs in the finance literature. Many of the studies dealing with iShares examine their historical performance, premium or discount to net asset value $(N A V)$, and their diversification value. Some of the studies focusing on iShares include, Jares and Lavin (2004), Zhong and Yang
(2005), Chu, Mazumder, Miller, and Prather (2007), and Tsai and Swanson (2009). Harper, Madura, and Schnusenberg (2006) study international iShares in comparison to closedend country funds. They find that international iShares outperform closed-end country funds, and argue that iShares provide a more efficient way to add diversification to a domestic portfolio. Tsai and Swanson (2009) agree with Harper et al. (2006), and find that iShares excel above closed-end country funds in terms of diversification value to the domestic investor. Jares and Lavin (2004), examining Japan and Hong Kong iShares, find a negative relation between current premium and performance which opens the possibility for profitable trading rules. Zhong and Yang (2005) examine European iShares and report that the U.S. market, in contrast to the home market, significantly affect iShares returns. Finally, Chu et al. (2007) show predictable returns patterns in 17 country-specific iShares. However, the authors conclude that taking advantages of these patterns can be very costly for investors.

The sample of ETFs I examine in this study include: iShares Brazil, iShares Brazil Small-Cap, iShares Chile, iShares Mexico and iShares Peru. I find that, although these ETFs show a close relationship between their net asset value and corresponding market price, other pricing factors are also important. Additionally, the iShares in the sample are more likely to trade at a premium than at a discount, and these deviations from net asset value tend to persist for at least a day.

the iShares website, www.ishares.com. Closing prices come from the Center for Research in Security Prices (CRSP). Market index levels and iShares trading volume come from Bloomberg. Each ishares in the sample is examined from its inception date until August 31, 2011.

\section{Table 1: Latin American iShares}

\begin{tabular}{|c|c|c|c|c|}
\hline Country & Ticker & Inception Date & Index & Stock Exchange \\
\hline Mexico & EWW & $3 / 12 / 1996$ & MSCI Mexico Investable market index & NYSE \\
\hline Brazil & EWZ & $7 / 10 / 2000$ & MSCI Brazil Index & NYSE \\
\hline Chile & $\mathrm{ECH}$ & $11 / 12 / 2007$ & MSCI Chile Investable Market Index & NYSE \\
\hline Perú & EPU & $6 / 19 / 2009$ & MSCI All Peru Capped Index & NYSE \\
\hline Brazil Small-Cap & EWZS & $9 / 28 / 2010$ & MSCI Brazil Small Cap Index & NYSE \\
\hline
\end{tabular}

Table 1 shows the five iShares included in this study. The data presented in Table 1 comes directly from the iShares website, and shows that the inception dates range from March 1996 to September 2010. The table also shows that all these iShares track indexes from the Morgan Stanley
Capital International index series and are traded on the NYSE. Table 2 provides some descriptive statistics on the aforementioned ETFs. The data presented in Table 2 is based on information provided in the iShares website as of June 30, 2011. Table 2 shows that these ETFs have very low 
expense ratios. iShares Mexico have the lowest expense ratio $(0.53 \%)$, while Brazil Small-Cap have the highest (0.65\%). In terms of assets, iShares Brazil is by far the largest with $\$ 12.69$ billion in assets. The other four ETFs have total net assets ranging from $\$ 0.06$ billion to $\$ 1.6$ billion. Table 2 also presents the number of portfolio holdings, and shows that iShares Peru have the fewest number of securities with 27. iShares Brazil includes the largest number of securities with 90 .

\section{Table 2: Summary statistics}

\begin{tabular}{|c|c|c|c|c|c|}
\hline Country & $\begin{array}{l}\text { Expense ratio } \\
(\%)\end{array}$ & $\begin{array}{l}\text { Net Assets } \\
\text { (\$billion) }\end{array}$ & $\begin{array}{l}\text { Price to } \\
\text { Earnings }\end{array}$ & Price to Book & \# of Holdings \\
\hline Mexico & 0.53 & 1.6 & 19.69 & 4.15 & 43 \\
\hline Brazil & 0.61 & 12.69 & 13.79 & 3.09 & 90 \\
\hline Chile & 0.61 & 0.86 & 19.78 & 2.91 & 40 \\
\hline Peru & 0.62 & 0.45 & 13.21 & 3.42 & 27 \\
\hline Brazil Small Cap & 0.65 & 0.06 & 20.47 & 2.31 & 78 \\
\hline
\end{tabular}

Notes: This table presents some descriptive statistics of the Latin American iShares included in this study. All the data is as of June 30,2011 and is based on information available in the iShares website.

\section{Methodology}

I investigate the price behavior, and deviations from NAVs or premiums of a sample of five country-specific Latin American iShares. The analysis presented here builds on previous works on ETFs which tracks indexes from the U.S. (Elton, Gruber, Comer and Li 2002), from Taiwan (Lin, Chan, Hsu 2006) from Turkey (Kayali, 2007) and from Germany (Rompotis, 2008).

\section{1 Prices}

The first issue I tackle in this paper is the relation between prices and NAVs. ETFs have both a market price, at which all trading occurs, and a net asset value. The NAV is the per-share portfolio value and a more accurate measure of fundamental value than market prices. The goal of this section is to tests whether iShares prices reflect all $N A V$ information, i.e., fundamental value. Similar to Lin, Chan, and Hsu (2006) and Kayali (2007), I test for the price efficiency of Latin American ETFs. Given the in-kind creation and redemption of ETFs, and contrary to the case of closedend funds, I expect high price efficiency. To test the price efficiency of this sample of ETFs I estimate the following regression model:

$$
N A V_{t}=\mathrm{a}+\mathrm{b} P_{t}
$$

where, $P_{t}$ is the ETF's closing market price at time $t$ and $N A V_{t}$ is the net asset value at time $t^{6}$.

\subsection{Premiums}

ETFs can trade at a premium or discount to NAV. Although the creation and deletion feature of ETFs should help to keep deviations from NAV at a minimum, it has been advocated in the literature that in many instances
ETFs trade at prices significantly different from their NAVs. Similar to Elton, Gruber, Comer and Li (2002), I define the percentage difference percentage $(d p)$ as:

$$
d p_{t}=\frac{P_{t}-N A V_{t}}{N A V_{t}}
$$

where, $P_{t}$ is the ETF's closing market price and $N A V_{t}$ is the net asset value, both at time $t$. If the percentage difference is positive, the ETF is selling at a premium, while a negative value indicates a discount. I also examine the persistence, or lack thereof, of the deviations from NAV. To this end, and as in Elton et al. (2002) and Kayali (2007), I estimate the following simple linear regression model:

$$
d p_{t}=\alpha+d p_{t-1}
$$

In this model I regress the percentage difference at time $t$ against the difference in percentage at time $t-1$.

\section{Empirical results}

\section{1 Prices}

In this section I present the results of the test of price efficiency for the sample of Latin American iShares included in the study. Table 3 presents the results of the estimation of Equation 1 and includes the estimates of the intercept and slope coefficient along with the corresponding $p$-values. I estimate the price efficiency for each ETF in the sample for a time period which starts on the inception date of each ETF and ends on August 31, 2011. 
Table 3: Latin American iShares Net Asset Value/Price Relation

\begin{tabular}{|l|r|r|r|}
\hline Name & Ticker & Intercept & Coefficient \\
\hline Mexico & EWW & 0.0173 & 1.0000 \\
\hline Brazil & & 0.0070 & 0.0000 \\
\hline Chile & EWZ & 0.0793 & 0.9952 \\
& & 0.0000 & 0.0000 \\
\hline Perú & ECH & 0.0260 & 0.9982 \\
\hline & & 0.6270 & 0.0000 \\
\hline Brazil & EPU & -0.2066 & 1.0057 \\
\hline Small-Cap & & 0.0040 & 0.0000 \\
\hline
\end{tabular}

Notes: This table presents the result of testing the price efficiency of the five Latin American iShares included in this study. To test the price efficiency of this sample of ETFs the following linear regression model: $N A V_{t}=\mathrm{a}+\mathrm{b}$ is estimated. $P_{t}$ is the ETF's closing market price and $N A V_{t}$ is the net asset value at time t. The time period of the analysis starts on the inception of each the iShares and ends in August 31, 2011.

In general, I find a high degree of price efficiency with all the coefficient estimates close to one and all statistically significant at one percent. The coefficient estimates ranges from a low of 0.8939 for iShares Brazil Small-Cap to a high of 1.0057 for iShares Perú. These coefficients are similar in magnitude to those reported in Lin et al. (2006) for Taiwan ETFs. However, aside from the case of iShares Chile, there is some evidence of deviation between NAV and market price for the other ishares in the sample. The estimate of the intercept for iShares Chile is the only intercept not statistically different from zero. The results for the other four iShares show intercepts which are statistically different from zero, indicating deviations in price from their underlying value and the existence of other important pricing factors. These deviations present both a cost and an opportunity to investors. This result is important because, given the in-kind creation/redemption feature of ETFs, one would expect to find all intercepts in Equation 1 not statistically different from zero (see Gatineau 2001; Lin, Chan, and Hsu 2006). This result shows that the in-kind creation/redemption process has its limitations as an effective arbitrage mechanism to prevent significant price deviations from the NAV of Latin American ETFs. In the next section, I explore in more details the premium/discounts of these Latin American iShares.

\subsection{Premiums}

Figure 1 shows a time series plot of the percentage difference. The graph shows the evolution of price differences over time. The price differences of iShares with the longest price history, Mexico, Brazil, and Chile, decrease over time. However, iShares with more recent inception dates show more variation in price differences.
The plot also shows a big spike around the 2008 financial crisis. Table 4 presents some descriptive statistics of the historical differences between the prices and NAVs of the five Latin American iShares. The results in Table 4 show that four out of the five ishares (Mexico being the exception) in the study trade mostly at premium, which is consistent with the evidence presented by Aber, Li, and Can (2009) on iShares, but contrary to Kayali (2007) on the examination of DJIST Turkey. Mexico has the longest trading history with 3877 days, while the youngest iShares in the sample is Brazil Small-Cap with 234 days. The median value of the percentage difference ranges from a low value of -0.0003 for iShares Mexico to a high of 0.0197 for Brazil Small-Cap. Table 4 also presents the percentage of days the ETFs close at a premium or a discount. iShares Mexico closed at a premium (NAV higher than market price) on 48.67 percent of the time, and is the only ETF in the sample most likely to trade at a discount (49.45 percent). iShares Brazil, Chile and Peru are more likely to trade at a premium with $58.18,60.59$ and 51.62 percent of the time closing at a price higher than $N A V$. iShares Brazil Small-Cap presents a surprising result, this ETF closes at a premium more than 95 percent of the time. Perhaps this result is due to the fact that iShares Brazil SmallCap is the youngest ETF in the sample with less than a year of price history.

\begin{tabular}{|l|r|r|r|r|}
\hline \begin{tabular}{l} 
Table 4: Premium/Discounts Latin American iShares \\
\hline Name
\end{tabular} & \multicolumn{1}{|l|}{ Days } & Median & $\begin{array}{l}\text { Days with } \\
\text { Premium } \\
\text { (\%) }\end{array}$ & $\begin{array}{l}\text { Days with } \\
\text { Discount } \\
\text { (\%) }\end{array}$ \\
\hline Mexico & 3877 & -0.0003 & 48.67 & 49.45 \\
\hline Brazil & 2769 & 0.0017 & 58.18 & 39.76 \\
\hline Chile & 954 & 0.0017 & 60.59 & 38.78 \\
\hline Perú & 554 & 0.0002 & 51.62 & 47.65 \\
\hline $\begin{array}{l}\text { Brazil } \\
\text { Small- } \\
\text { Cap }\end{array}$ & 234 & 0.0197 & 95.72 & 3.85 \\
\hline
\end{tabular}

Notes: This table presents some descriptive statistics of the premium and discount to net asset value of the five Latin American iShares included in the study. The percentage difference $(d p)$ is defined as:

$$
d p_{t}=\frac{P_{t}-N A V_{t}}{N A V_{t}}
$$

where, $P_{t}$ is the ETF's closing market price and $N A V_{t}$ is the net asset value at time $t$. If the difference percentage is positive, the ETF is selling at a premium, while negative values indicate a discount. The time period of the analysis starts on the inception of each the iShares and ends in August 31, 2011. 
Figure 1.

Figure 1a: Percentage Difference iShares Mexico

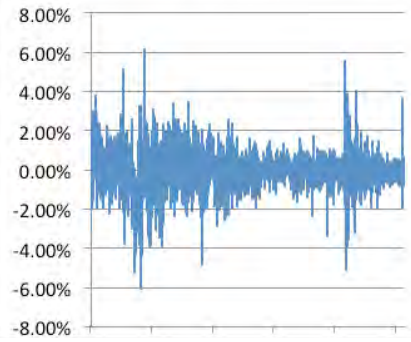

Figure 1c: Percentage Difference iShares Chile

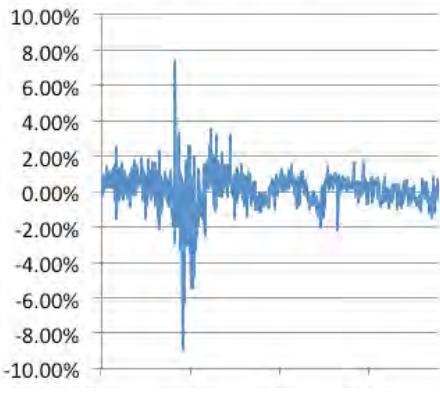

Figure 1e: Percentage Difference iShares Brazil Small-Cap

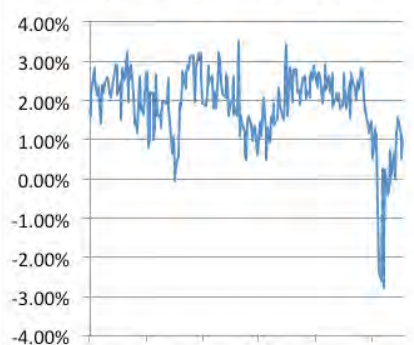

In terms of dollars and cents, the difference corresponds to average absolute differences between closing market prices and net asset values of as high as 58 cents for iShares Brazil Small-Cap, and as low as 23 cents for iShares Brazil. For iShares Mexico and iShares Chile the average absolute difference is 34 cents and for iShares Peru is 39 cents. These differences are much higher than those reported by Elton et al. (2002) for the Spiders.

\section{Concluding Remarks}

Exchange traded funds are one of the most popular new investment vehicles available to investors. ETFs are similar to open-end mutual funds but can be traded during the day like any other common stock. In fact, many ETFs are on the list of the most traded securities in exchanges around the world. In this study, I examined two issues (prices and premiums) related to ETFs using Latin American countryspecific iShares. The sample includes two ETFs from Brazil,
The results presented here point to the fact that, most of time, this sample of ETFs trade at prices which are different from NAV. As these differences might present opportunities for arbitrage or hint hidden costs to investors, it is important to examine the persistence in deviations from NAVs. To this end, I estimate Equation 3 and the results are presented in Table 5. The results show that indeed deviations from NAV do persist, at least for a day. The slope coefficient ranges from 0.3708 to 0.7446 . More importantly, the lag percentage difference explains as much as 55 percent the variation in percentage difference. The evidence is stronger for the ETFs with the shortest history, that is, ishares Peru and iShares Brazil Small-Cap. This evidence points to the fact that investors are not able to sufficiently take advantages of the arbitrage opportunities provided by these ETFs. Another explanation might be that trading costs and other market imperfections prevent investors from profiting from these deviations.

Table 5: Percentage Difference Persistence

\begin{tabular}{|l|r|r|r|}
\hline Name & Intercept & \multicolumn{2}{l|l|}{$\begin{array}{l}\text { Lag } \\
\text { percentage } \\
\text { difference }\end{array}$} \\
\hline Mexico & -0.0004 & 0.3718 & 13.8 \\
\hline Brazil & 0.0080 & 0.0000 & \\
\hline Chile & 0.0011 & 0.3710 & 13.8 \\
& 0.0000 & 0.0000 & \\
\hline Perú & 0.0008 & 0.3708 & 13.7 \\
& 0.0150 & 0.0000 & \\
\hline Brazil & 0.0000 & 0.7245 & 53.5 \\
\hline Small-Cap & 0.8670 & 0.0000 & \\
\hline
\end{tabular}

Notes: This table presents the result of estimating the persistence of the price deviations from NAV of the five Latin American iShares included in the study. The table shows the results of the estimation the following simple linear regression model: , where $d p$ is the percentage difference. The time period of the analysis starts on the inception of each the iShares and ends in August 31, 2011.

and ETFs from Mexico, Chile and Peru. While I find evidence of a high level of price efficiency but also find that other factors, besides fundamental value, could affect prices. In fact, most of the ETFs in the sample are more likely to trade at a premium than at a discount and this deviation persist for at least day. These deviations from net asset value may indicate arbitrage opportunities. 


\section{References}

Aber, J. W., Li, D., and Can, L. (2009), Price volatility and tracking ability of ETFs. Journal of Asset Management, 10(4), 210-221.

Chu, T. H., Mazumder, M. I., Miller, E. M., and Prather, L. J. (2007), Exploitable cross autocorrelations among iShares. Financial Services Review, 16(4).

Elton, E., Gruber, M., Comer, G., and Li, K. (2002), Spiders: where are the bugs? Journal of Business, 75(3), 453-472.

Gastineau, G. L. (2001), Exchange-traded funds: An introduction. The Journal of Portfolio Management, 27(3), 88-96.

Harper, J. T., Madura, J., and Schnusenberg, O. (2006), Performance comparison between exchange-traded funds and closed-end country funds. Journal of International Financial Markets, Institutions and Money, 16(2), 104-122.

Jares, T., and Lavin, A. (2004), Japan and Hong Kong exchange-traded funds (ETFs): Discounts, returns, and trading strategies. Journal of Financial Services Research, 25(1), 57-69.
Kayali, M. M. (2007), Pricing efficiency of exchange traded funds in Turkey: early evidence from the Dow Jones Istanbul 20. International Research Journal of Finance and Economics, 10, 14-23.

Lin, C. C., Chan, S. J., and Hsu, H. (2006), Pricing efficiency of exchange traded funds in Taiwan. Journal of Asset Management, 7(1), 60-68.

Shin, S., and Soydemir, G. (2010), Exchange-traded funds, persistence in tracking errors and information dissemination. Journal of Multinational Financial Management, 20(4), 214234.

Tsai, P. J., and Swanson, P. E. (2009), The comparative role of iShares and country funds in internationally diversified portfolios. Journal of Economics and Business, 61 (6), 472494.

Tse, Y., and Martinez, V. (2007), Price discovery and informational efficiency of international iShares funds. Global Finance Journal, 18(1), 1-15.

Zhong, M., and Yang, H. (2005), Risk Exposures and International Diversification: Evidence from iShares. Journal of Business Finance and Accounting, 32(3/4), 737-771.

\section{Note}

1. Based on data from the Investment Company Institute available in www.ici.org.

2. ETFs basics: How to Invest in Emerging Markets, U.S. News Online Edition, October 21, 2010. Five Myths About emerging Markets, Wall Street journal Online Edition, December 5, 2011.

3. See for example: Opportunities in Latin American ETFs, Investor Chronicle, April 17, 2013.

4. Studies include: Tsai and Swanson (2009), and Shin and Soydemir (2010) among others.

5. Based on the data provided by the iShares website www.ishares.com.

6. A unit root test on the residuals of Equation 1 show that the variables are cointegrated.

\section{Corresponding Author:}

Javier Rodríguez, Ph.D., Professor - Finance, University of Puerto Rico, Graduate School of Business, PO Box 23332, San Juan PR 00931. Email javier.rodriguez19@upr.edu 